\title{
Para Mujtahid Pada Era Sahabat dalam Kaitan Mazhab Shahabiy
}

Mursyid

Dosen UIN Ar-Raniry Banda Aceh

Email mursyid76@gmail.com

\begin{abstract}
Abstrak
Era sahābat memiliki peran yang signifikan dalam perkembangan fiqh karena pada era sahābat, hukum Islam mulai berinteraksi dengan peradaban Persia dan Romawi yang menimbulkan beberapa persoalan baru, terutama dalam persoalan mu'āmalah. Persoalan baru yang dihadapi ini belum pernah dihadapi oleh umat Islam sebelumnya, bahkan persoalan tersebut belum pernah muncul pada masa Rasulullah. Para Sahābat kemudian merumuskan dan mengejewantahkan bagaimana posisi Islam dalam berinteraksi dengan kedua peradaban tersebut. Pada konteks inilah penelitian ilmiah tentang sebaran sahābat dan implikasinya terhadap mazhab sahabiy menarik untuk dikaji dalam rangka melahirkan konsep fiqh yang relevan dengan kondisi masyarakat yang terus bergerak ke dalam satu fase baru sejarah, yaitu dunia modern. Secara sepesifik, penelitian ini berfokus pada kajian sebaran sahābat dengan menekankan pada siapa-siapa saja sahābat yang menjadi mujtahid pada periode sahabat dan di daerah mana mereka tersebar serta bagaimana pengaruh sebaran sahābat terhadap Mazhab sahābī.
\end{abstract}

Kata Kunci: Sebaran, sahabat dan Mazhab Sahabiy

\section{Pendahuluan}

Mayoritas penulis sejarah fiqh seperti; Abdul Wahab Khallaf ${ }^{1}$, Muhammad Yusuf Musa², Muhammad Ali al-Sāyis³, Umar Sulaiman al-Asyqar, dan

1 Abdul Wahab Khallaf, Ilmu Ushūl al-fiqh wa Khulāshat al-Tasyri al-Islām, (Mesir: t.p. 1942), h. 2. 
Syaikh Muhammad al-Khudari Bek ${ }^{5}$ menempatkan periode Rasul sebagai periode pertama dari perkembangan hukum Islam (fiqh) dengan memberikan label bahwa periode Rasulullah sebagai periode pertumbuhan atau permulaan fiqh.

Berbeda dengan Ahmad Ibrahim Bek, ia tidak menempatkan periode Rasul sebagai periode awal dari perkembangan fiqh. Alasannya bahwa syari 'ah berbeda dengan fiqh. ${ }^{6}$ Menurutnya syari'ah berakhir dengan wafatnya Rasulullah saw karena Allah adalah satu-satunya pembuat syari'ah (al-Syāri') dan Muhammad sebagai pembawa syari'ah tersebut. Adapun apa yang sesudah wafatnya Rasul adalah kegiatan ijtihādi dari fuqahă sahābat, tābi īn dan kaum muslimin sesudahnya. $^{7}$

Secara ilmiah, pendapat Ahmad Ibrahim Bek lebih argumentatif karena kenyataannya fiqh merupakan hasil pemahaman manusia terhadap nash, atau dengan kata lain, fiqh adalah hasil interaksi antara nash (Al-Qur 'àn dan Hadith), rasio (ijtihād) dan peristiwa/fakta empirik ${ }^{8}$. Adapun sebelum era sahābat, lebih

2 Muhammad Yusuf Musa, Al-Madkhal Li Dirāsat al-Fiqh al-Islām, (Mesir: Dār alFikr al-Araby, 1961), h. 22.

${ }^{3}$ Muhammad Ali Al-Sāyis,, Tārikh al-Fiqh al-Islām, (Cet; Beirut: Dār al-Kutub alIlmiyyah, 1990), h. 14.

4 Umar Sulaiman al-Asyqar, Fiqh Islam: Sejarah Pembentukan dan Perkembangannya, (Cet. I; Jakarta: Akademika Pressindo, 2001), h. 45.

5 Syaikh Muhammad al-Khudari Bek, Tarikh al-Tasyri' Al-Islami, (Beirut: Dār al-Fikr, t.th.), h. 4.

${ }^{6}$ Dalam kajian ilmiah, antara fiqh dan syari'ah memang sangat berbeda. Khaled M Abou El-Fadl menjelaskan bahwa syari'ah adalah hukum Tuhan sebagai sesuatu yang abstrak (secara etimologis berarti jalan), sementara figh adalah pemahaman dan pelaksanaan konkret kehendak Tuhan. Dengan kata lain, syari'ah adalah kehendak Tuhan yang abstrak dan ideal, tapi figh merupakan hasil dari upaya manusia memahami kehendaak Tuhan. Lihat Khaled M Abou El-Fadl, Atas Nama Tuhan: Dari Fikih Otoriter ke Fikih Otoritatif, (Cet. I; Jakarta: PT. Serambi Ilmu Nusantara, 2004), h. 61.

7 Ahmad Ibrahim Bek, Ilmu Ushul al-Figh wa Yalih Tarikh al-Tasyri' al-Islam, (Mesir: Dar al-Anshar. 1939), h. 4-46.

8 Figh secara etimologi, bermakna pengertian, pemahaman. Ahmad Warson Munawwir, Al-Munawwi: Kamus Arab Indonesia (Yogyakarta : Krapyak, 1984), hal. 1148. Dalam kamus Tartib al-Qāmus al-Muhīt, الفقه diartikan العلم بالثيئ و الفهم له yaitu ilmu tentang sesuatu dan pemahaman tentangnya. Lihat, Al-Tāhir Ahmad al-Zāwy, Tartib al-Qamus alMuhìt, Juz. III; (Cet. III; Beirut: Dār al-Fikr, t.th), h. 513. Defenisi yang lebih detail tentang figh dari segi etimologi ditemukan dalam Mu'jam Maqāyis. Dalam kamus ini dikemukakan bahwa setiap pengetahuan tentang sesuatu adalah figh. Kemudian, kata ini dikhususkan dalam term ilmu syari'ah sehingga setiap orang yang mengetahui tentang halal dan haram di sebut fäqih. Lihat, Abi al-Husain bin Zakariyah, op. cit., h. 442. 
dikenal sebagai era tasyri//pensyari'atan (era syari $\left.^{\star} a h\right)^{9}$ yaitu era ketika Nabi Muhammad saw masih hidup. Namun demikian, dalam kajian fiqh, era sahābat dianggap sebagai cikal bakal terjadinya perselisihan di antara para fuqahā sesudahnya. Banyak data yang telah dikemukakan oleh para ahli hukum Islam menunjukkan bahwa perbedaan fuqahă ${ }^{`}$ pada masa belakangan adalah proses berkelanjutan dari perbedaan pemahaman sahābat terhadap suatu persoalan pada masanya. ${ }^{10}$

Terlepas dari perbedaan pendapat tentang permulaan fiqh di atas, era sahābat dianggap memiliki peran yang signifikan dalam perkembangan fiqh. ${ }^{11}$ Pada era sahābat, hukum Islam mulai berinteraksi dengan persoalan-persoalan baru. Pada masa sahābatlah pertemuan antara pelbagai peradaban, budaya dan sebagainya semakin intensif. Bahkan, Pada masa sahābat, pertemuan antara Islam dan dua peradaban besar saat itu (Persia dan Romawi) menemukan puncaknya. Dari pergumulan dengan Persia dan Romawi ini, menimbulkan beberapa persoalan baru, terutama dalam persoalan mu'āmalah. Persoalan baru yang dihadapi ini belum pernah dihadapi oleh umat Islam sebelumnya, bahkan persoalan tersebut belum pernah muncul pada masa Rasulullah. ${ }^{12}$

9 Syarīah secara etimologi paling tidak memiliki dua makna. Menurut Ibnu Faris Zākariyah, Syarīáh berarti sesuatu yang dibuka lebar untuk dijalani. Lihat Abi al Husain Ahmad Ibnu Fāris Zakariyyah, Mu'jam Maqāyis al-Lugah, Juz III (Beirut: Dār al-Fikr, t.th), h. 262. Sedangkan menurut Ibnu Mandzur Jamaluddin, Syarī'ah berarti jalan menuju sumber air. Muhammad Fuād 'Abd alBāqy, Al-Mu'jam al-Mufahras li al-Fāž al-Qur'an al-Karìm (Cet. I; Mesir: Dār al Hadith, 1996), h. 465. Secara terminologi, syarīal menurut Mahmud Syaltūt, syarīah adalah peraturan yang diturunkan Allah kepada manusia agar dipedomani dalam berhubungan dengan Tuhannya, dengan sesamanya, dengan lingkungannya, dan dengan kehidupan. Mahmud Syalt-t, Al-Islam 'Aqidah wa Syari'ah, (Kairo: Dār al-Qalam, 1966), h. 12.

${ }^{10}$ Pendapat semcamam ini dapat ditelusuri dalam berbagai kitab figh, khususnya sejarah sosial hukum Islam. Muhyiddin misalnya, berpendapat bahwa semua perbedaan pendapat yang muncul diakibatkan oleh faktor yang beraneka ragam yang bermula dari generasi sahabat yang kemudian berkembang pada ulama Figh mutagaddimin dan mutakhkhirin. Muhyiddin Abdussalam Al-Baltaji, Mauqif Al-Imam al-Syafi'i Min Madrasah Al- Iraq al-Fiqhiyyah (Mesir, t.th.), h. 79-80.

11 Periode sahabat merupakan periode yang sangat penting dalam kajian figh bahkan dalam kajian keislaman secara keseluruhan --karena merupakan periode (generasi) yang unik, yang tidak tertandingi oleh periode (generasi muslim) manapun. Mereka dianggap unik karena hanya merekalah generasi umat Islam yang pernah bertemu dengan Rasulullah. Lihat Alyasa' Abu Bakar, Fatwa Sahabat Sebagai Paradigma Fiqih Mazhab, [Makalah], Banda Aceh, 25 Agustus 2004), h. 5.

12 Abdul Wahhab al-Khallaf, 'Ilm Ushul al-Figh (Cet. XII; Mesir: Dar al-Ilm, 1978), h. 15 . 
Para Sahābat kemudian merumuskan dan mengejewantahkan bagaimana posisi Islam dalam berinteraksi dengan kedua peradaban tersebut. Selanjutnya, setiap persoalan baru yang muncul, diselesaikan oleh sahābat, berdasarkan hasil ijtihād atau fatwa. Kegiatan ijtihād ini dilakukan oleh para sahābat berdasarkan daerah sahābat berdomisili. Intensitas dari Aktifitas ijtihād sahābat ini tentu sangat beragam berdasarkan periode khalifah yang berkuasa pada era al-khulafã' alı̄̄ syidūn.

Pada konteks inilah penelitian ilmiah tentang mujtahid pada era sahābat dan implikasinya terhadap mazhab sahabiy menarik untuk dikaji dalam rangka melahirkan konsep fiqh yang relevan dengan kondisi masyarakat yang terus bergerak ke dalam satu fase baru sejarah, yaitu dunia modern yang ditandai dengan perkembangan ekonomi, ilmu pengetahuan dan teknologi serta revolusi dalam teknologi informasi dan komunikasi. ${ }^{13}$

\section{Pembahasan}

\section{Pengertian Sahabat}

Sahabat dalam kamus bahasa Indonesia diartikan sebagai kawan, teman, dan handai. ${ }^{14}$ Dalam kamus Al-Munjid, الصحابة diartikan sebagai sahabat-sahabat Nabi yang muslim yang melihat Nabi serta persahabat mereka panjang. ${ }^{15}$ Dari pengertian secara etimologi tersebut sahabat nampaknya sudah diartikan sebagai istilah teknis sebagai sahabat Nabi Muhammad SAW. Untuk term sahabat yang digunakan secara umum (sepadan dengan term sahabat dalam bahasa Indonesia) digunakan istilah صاحب yang bentuk jamaknya adalah أصحاب.

Adapun sahabat menurut istilah, terdapat beberapa pengertian yang dikemukakan baik oleh para ahli hadis maupun ahli fiqh/ushul fiqh. Untuk memahami pengertian sahabat menurut pendapat ahli ini, berikut pendapat mereka dikemukakan secara berurut:

\footnotetext{
13 Saat ini, sebagian antropologi berpendapat bahwa manusia tidak lagi berada dalam dunia modern. Akan tetapi sudah memasuki dunia baru, yaitu postmodernisme yang ditandai dengan de-industrialisasi, pemadatan ruang waktu, decentering subjek manusia, ketidaksinambungan. Achmad Fedyani Saifuddin, Antropologi Kontemporer: Suatu Pengantar Kritis Mengenai Paradigma (Cet. I; Jakarta: Kencana, 2005), h. 44-45.

14 Tim Penyusun Kamus Pusat Bahasa, Kamus Besar Bahasa Indonesia, Edisi III, (Cet. III; Jakarta: Balai Pustaka, 2005), h. 977.

15 Louis Ma'luf, Al-Munjid Fii Al-Lugah wal A'lam (Cet. XXXIII; Beirut: Dar AlMasyriq, 1992), h. 416.
} 
Sahabat menurut jumhur ahli hadis adalah orang Islam yang pernah bergaul atau melihat Nabi, dan meninggal dalam keadaan Islam. ${ }^{16}$ Menurut Ajjaj Al-Khatib dalam karyanya Ushul al-Hadis sahabat adalah setiap orang muslim yang hidup bergaul bersama Rasulullah dalam waktu yang cukup lama serta menimba ilmu dari Rasulullah. Sedang Menurut Utsman bin Salih, yang dikatakan sahabat adalah orang yang menemui masa Nabi, walaupun dia tidak dapat melihat Nabi dan memeluk Islam semasa Nabi masih hidup. ${ }^{17}$

Menurut Ibn Hajar Al-Asqalani, sahabat adalah orang yang berjumpa dengan Nabi SAW dalam keadaan mukmin, dan meninggal dalam keadaan Islam baik dia bergaul lama dengan Nabi atau tidak, baik dia meriwayatkan hadis dari Nabi atau tidak, baik dia turut berperang bersama Nabi atau tidak, baik dia dapat melihat Nabi tetapi tidak duduk semajlis dengan Nabi atau tidak dapat melihat Nabi karena buta. ${ }^{18}$

Khudary Bek mengemukakan bahwa tidak dipandang seseorang menjadi sahabat melainkan orang yang berkediaman beserta Rasulullah, setahun at au dua tahun. ${ }^{19}$ Sementara Wahbah Al-Zuhaili membedakan sahabat menurut ahli ushul dan sahabat menurut ahli hadis. Menurut ahli ushul, sahabat adalah orang yang berjumpa dengan Rasulullah saw dalam keadaan mukmin dan menyertai Rasulullah dalam rentang waktu yang lama. Sedang menurut ahli hadis sahabat adalah orang yang berjumpa dengan Rasulullah saw dalam keadaan muslim dan meninggal dalam keadaan muslim, baik ia lama bergaul dengan Rasulullah atau tidak. $^{20}$

Menurut Ibn Hazm, sahabat adalah setiap orang yang duduk semajlis dengan Nabi SAW meskipun hanya sekali waktu saja, mendengar sabda Nabi meskipun hanya satu kata, atau menyaksikan sebuah perkara dari Nabi SAW serta tidak menjadi munafik sampai dia wafat. ${ }^{21}$

16 Menurut Syuhudi Isma'il, Pengertian ini dianut oleh mayoritas ulama hadis semisal Ibn Shalah, Ibn Katsir, Al-Suyuthi dan Al-Sakhawy. Syhuhudi Isma'il, Kaedah Kesahihan Sanad Hadis: Telaah Kritis dan Tinjauan dengan Pendekatan Sejarah (Cet. II; Jakarta: Bulan Bintang, 1995), h. 160.

17 Teungku Muhammad Hasbi Ash Shiddieqy, Sejarah dan Pengantar Ilmu Hadis (Cet. VIII; Semarang: Pustaka Rizki Putra, 2001), h. 238.

18 Ahmad bin 'Ali bin Hajar Al-AsqalanI, Al-Ishabah Fii Tamyizi Al-Sahabah, Juz. I, (Mesir: Al-Maktabah Al-Taufiqiyah, t.th), h. 7.

19 Ibid., h. 239.

${ }^{20}$ Wahbah Al-Zuhaili, Ushul Fiqh Al-Islami, Juz II (Cet. III; Surya: Dar Al-Fikr, 2005) h. 150.

21 Abi Muhammad Ali bin Ahmad bin Said bin Hazm, Al-Ihkam Fi Ushul alAhkam, Jilid V, (Beirut: Dar Al-Kutub Al-Ilmiyyah, t.th.), h. 76. 
Defenisi Ibn Hazm di atas, tidak jauh berbeda dengan defenisi para ahli hadis. Bahkan jika ditelusuri lebih jauh ulasan Ibn Hazm setelah mengemukakan defenisi sahabat di atas, maka ditemukan penegasannya bahwa barang siapa yang termasuk dalam kategori sahabat di atas, maka dia termasuk sahabat yang semuanya adalah adil ${ }^{22}$, imam fadhil. ${ }^{23}$

Dari pengertian sahabat menurut pakar hadis dan pakar fiqh/ushul fiqh di atas, maka dapat ditemukan perbedaan yang tajam antara dua disiplin ilmu ini. Pakar di bidang hadis berpendapat bahwa bila seseorang telah berjumpa dengan Nabi dan menjadi muslim maka dia termasuk sahabat Nabi meskipun tidak lama bergaul bersama Nabi. Sedangkan menurut ahli fiqh/ushul fiqh orang yang dipandang sahabat adalah orang yang berjumpa dengan Nabi dan memeluk Islam serta bergaul lama dengan Nabi setahun, dua tahun atau lebih.

Atas dasar perbedaan pengertian sahabat yang dikemukakan oleh para ahli di atas, maka penetapan jumlah orang yang disebut sahabat pun juga berbeda. Menurut Bukhari, sahabat Rasul di waktu Rasulullah wafat, berjumlah 114.000 orang sahabat. ${ }^{24}$

\section{Sahabat yang Memiliki Kualifikasi Mujtahid}

Pada kajian sebelumnya telah dikemukakan pertanyaan tentang Siapakah sahabat Rasulullah yang termasuk mujtahid? Apakah semua sahabat Rasulullah adalah mujtahid?

Dalam menelusuri persoalan ini, penulis menemukan bahwa Ibn Hazm telah membuat kategori/pengelompokan sahabat yang lebih spesifik diarahkan pada kapasitasnya sebagai ahli fiqh dan ushul fiqh. Kategori yang dimaksud adalah bahwa Ibn Hazm membuat kategori sahabat dalam 3 kelompok berdasarkan sedikit banyaknya jumlah fatwa yang dikeluarkan oleh sahabat. Kelompok pertama disebut al-muktsiruun (kelompok sahabat yang memiliki banyak fatwa), kelompok kedua disebut al-mutawassithun (sahabat yang jumlah fatwanya

22 Dalam kajian ahli hadis, yang dimaksud dengan adil adalah beragama Islam, mukallaf, melaksanakan ketentuan agama dan memelihara muru'ah. Khusus untuk periwayat pada tingkat sagabat, terdapat postulat tentang sahabat yaitu kullu sahabah aduul (setiap sahabat adalah adil). Terminologi adil merupakan salah satu syarat sebuah hadis masuk dalam kategori sahih. Syarat yang lain adalah sanadnya bersambung, periwayatnya bersifat dhabith, terhindar syadz dan terhindar dari illat. Syhuhudi Isma'il, Kaedah Kesahihan..... h. 127-153.

${ }^{23}$ Abi Muhammad Ali bin Ahmad bin Said bin Hazm, Al-Ihkam......, h. 76.

24 Teungku Muhammad Hasbi Ash-Shiddieqy, op. cit., h. 243. 
pertengahan) kelompok ketiga, disebut muqillun (sahabat yang jumlah fatwanya sedikit). ${ }^{25}$

Dari kategorisasi ini, dapat dipahami bahwa menurut Ibn Hazm, sahabat yang dapat disebut memiliki kualifikasi sebagai mujtahid adalah sahabat yang memiliki fatwa pribadi dalam bidang hukum Islam. Dari sini dapat ditemukan benang merah antara pendapat Ibn Hazm dengan para pakar fiqh/ushul fiqh, yaitu seorang sahabat yang tidak lama bergaul bersama Nabi kemungkinan tidak dapat memberikan fatwa di bidang hukum Islam karena itulah pakar fiqh/ushul fiqh yang lain mensyaratkan bahwa yang disebut sahabat Nabi, harus memiliki durasi yang lama dalam kebersamaan dengan Nabi.

Untuk mengetahui lebih jauh siapa saja sahabat yang memiliki kualifikasi sebagai mujtahid, maka penulis akan mengemukakan hasil penelusuran penulis tentang sahabat yang telah dikelompokkan oleh Ibn Hazm ke dalam 3 kelompok seperti yang telah dikemukakan di atas.

Dalam temuan penulis, Ibn Hazm mengkategorikan sahabat berdasarkan jumlah fatwa yang dikeluarkan oleh sahabat. Dalam hal ini Ibn Hazm, mengkategorikan sahabat dalam 3 kategori $^{26}$, yaitu sebagai berikut:

\section{Sahabat yang jumlah fatwanya banyak (al-muktsirun)}

Menurut Ibn Hazm, sekiranya fatwa setiap sahabat ini dikumpulkan, maka akan terdiri dari setiap fatwa sahabat ada satu buku. Sahabat yang masuk dalam kategori ini ada beberapa orang, seperti; A'isyah Ummul Mukminin, Umar bin al-Khaththab, Abdullah bin Umar bin al-Khaththab, Ali bin Abi Thalib, Abdullah bin Abbas, Abdullah bin Mas'ud dan Zaid bin Tsabit.

\section{Sahabat yang jumlah fatwanya pertengahan (al-mutawassithun)}

Sahabat yang masuk dalam kategori ini berjumlah 13 orang, Menurut Ibn Hazm, jika sekiranya masing-masing sahabat dikumpulkan fatwanya, maka hanya menghasilkan juz (semacam sub bab) yang amat tipis. Mereka adalah: Ummu Salmah (Ummul Mukminin), Anas bin Malik, Abu Sa'id Al-Khudhri, Abu Hurairah, Utsman bin Affan, Abdullah bin Umar bin Ash, Abdullah bin Zubair dan lain-lain.

\section{Sahabat yang jumlah fatwanya sedikit (muqillun)}

Kategori ketiga ini hanya mengeluarkan fatwa pada satu atau dua permasalahan saja. Kalau dikumpulkan secara keseluruhan fatwa mereka, hanya akan

\footnotetext{
${ }^{25}$ Abi Muhammad Ali bin Ahmad bin Said bin Hazm, Al-Ihkam... h. 89-90.

${ }^{26}$ Abi Muhammad Ali bin Ahmad bin Said bin Hazm, Al-Ihkam...op. cit., h. 89-90.
} 
menghasilkan satu juz yang kecil saja. Sahabat yang masuk dalam kategori ini adalah sepert; Abu Darda, Abu Al-Yasr, Abu Salmah Al-Makhzumi, Abu Ubaidah bin Al-Jarrah, Said bin Zaid, Hasan bin Ali bin Abi Thalib, Husain bin Ali bin Abi Thalib, Nu'man bin Basyir, dan lain-lain.

Jika mengikuti pendapat Ibn Hazm di atas, maka sahabat yang memiliki kualifikasi mujtahid adalah sebanyak hanya beberapa orang sahabat saja. Jika dibandingkan dengan total sahabat sepeninggal Rasulullah yakni 114.000 orang sahabat, maka dapat dikatakan bahwa sahabat yang memiliki kualifikasi mujtahid sangat sedikit.

\section{Sebaran Mujtahid pada Era Sahabat}

Sebagaimana telah dikemukakan di atas, bahwa dengan mengikuti pendapat Ibn Hazm di atas, maka dapat diketahui bahwa sahabat yang memiliki kualifikasi mujtahid adalah hanya beberapa orang saja yang masuk dalam 3 kelompok di atas.

Lebih lanjut yang ingin dibahas dalam artikel ini adalah bagaimana sebaran sahabat yang memiliki kualifikasi mujtahid tersebut. Untuk membahas hal tersebut, maka ada beberapa pertimbangan yang harus diperhatikan, yaitu (1) sebaran sahabat yang hendak diamati adalah sahabat yang memiliki kualifikasi mujtahid, (2) daerah sebaran sahabat yang hendak diamati adalah daerah yang dalam kajian hukum merupakan daerah yang memiliki atau dikenal sebagai daerah geografis yang besar dalam kajian hukum Islam, dan (3) referensi yang digunakan dalam melacak peta sebaran sahabat adalah referensi dalam kajian sejarah perkembangan fiqh dan sejarah perkembangan hadis.

Berdasarkan 3 hal di atas ditambah lagi dengan terbatasnya waktu yang dimiliki peneliti, maka penulis membatasi diri pada beberapa sahabat yang ingin diamati sebarannya serta mendasarkan peta sebaran sahabat yang dikenal dalam kajian sejarah perkembangan fiqh dan sejarah perkembangan hadis.

Dalam buku yang ditulis oleh Muhammad Ali As- Sayis, ketika menjelaskan perkembangan fiqh periode al-khulafa' al-rasyidun, penulis menemukan bahwa secara garis besar masalah yang dikaji adalah (1) kondisi hukum Islam pada periode sahabat, (2) sumber hukum pada periode sahabat, dan (3) contoh perbedaan pendapat sahabat, dan (4) biografi beberapa sahabat (dalam hal ini yang dikemukakan adalah Umar bin Khaththab, Zaid bin Tsabit,Abdullah bin Umar, Ibnu Mas'ud) ${ }^{27}$

${ }^{27}$ Muhammad Ali As- Sayis, ibid., h. 58-92. 
Dari sistimatika bahasan yang dikedepankan oleh Muhammad Ali As- Sayis di atas, maka bisa dikatakan bahwa ia tidak memberikan perhatian banyak tentang kualifikasi sahabat yang masuk dalam kategori mujtahid serta bagaimana sebaran mereka pada periode al-khulafa' al-rasyidun. Meskipun demikian penulis dapat mengetahui sedikit informasi sebaran beberapa sahabat yang diulas biografinya seperti; Umar bin Khaththab (berdomisili di Medinah), Zaid bin Tsabit (berdomisili di Medinah), Abdullah bin Umar (wafat di Mekah), Ibnu Mas'ud (diutus oleh khalifah Umar bin Khaththab sebagai ketua Baitul Mal di Kufah).

Dalam buku Ahmad Hasan yang berjudul Pintu Ijtihad Sebelum Tertutup, ditemukan bahwa sentra kajian hukum pada masa sahabat ada 3, yaitu (1) Hijaz (Mekah dan Medinah), (2) Iraq (Kufah dan Bashrah) dan (3) Syiria. Tokoh-tokoh mujtahid yang disebutkan adalah Umar bin Khaththab (Medinah), Aisyah (Medinah), Ibnu Umar (Medinah), Ali bin Abi Thalib (Kufah), Abdullah Ibnu Mas'ud (Kufah) ${ }^{28}$

Dalam buku Teungku Muhammad Hasbi Ash-Shiddieqy yang berjudul Sejarah dan Pengantar Ilmu Hadis, penulis menemukan bahwa sentra kajian Hadis pada masa sahabat adalah (1) Madinah; Abu Bakr, Umar, Ali (sebelum pindah ke Kufah), Abu Hurairah, Aisyah, Ibnu Umar, Abu Said Al-Khudry dan Zaid bin Tsabit, (2) Makkah; Muadz bin Jabal, Ibnu Abbas, (3) Kufah; Ali, Abdullah bin Mas'ud, Sa'ad bin Abi Waqqash, Sa'id bin Tsabit, Said bin Ziyad, Khabbab ibn Arat, Salman Al-Farisi, Huzaifah Ibnul Yaman, Ammar bin Yasir, Abu Musa, AlBaraq, Al-Mughirah, Al-Nu'man, Abul Thufail, Abu Juhaifah, (4) Bashrah; Anas bin Malik, Utbah, Imran bin Husain, Abu Bazrah, Ma'qil ibn Yasar, Abu Bakrah, Abdurrahman ibn Samurah, Abdullah ibn Syikhkhir, Jariah ibn Qudamah, (5) Syam; Mu'adz bin Jabal, Ubadah ibn Shamit dan Abu Darda', dan ( ) Mesir; Abdullah ibn Amer, Uqbah ibn Amir, Kharijah ibn Huzaifah, Abdullah ibn Sa'ad, Mahmiyah ibn Juz, Abdullah ibn Haris, Abu Basyrah, Abu Sa'ad Al-Khair, Mu'adz ibn Anas Al-Juhary. ${ }^{29}$

Dari sentra kajian hadis yang disebutkan oleh Teungku Muhammad Hasbi AshShiddieqy di atas dapat ditarik benang merah bahwa sentra kajian Hadis pada masa sahabat juga merupakan sentra kajian hukum Islam pada masa sahabat. Hal ini dapat dilihat pada kesesesuaian beberapa nama yang disebut sebagai tokoh hadis juga merupakan tokoh sahabat yang memiliki kualifikasi sebagai mujtahid.

Implikasi Sebaran Sahabat terhadap Mazhab sahā bì

28 Ahmad Hasan, Pintu Ijtihad Sebelum Tertutup, [Terj.], (Cet. II; Bandung: Pustaka, 1994), h. 18-19.

29 Teungku Muhammad Hasbi Ash-Shiddieqy, Ibid., h. 55-57. 
Para pakar ushul fiqh beragam menggunakan istilah mazhab sahābī. Di antara istilah yang digunakan adalah Qaul al-Sahabiy ${ }^{30}$, Fatwa al-Sahabiy ${ }^{31}$, Mazhab $s a h \bar{a} b \bar{i}^{32}$ yang telah dirumuskan oleh para ahli ushul fiqh.

Mazhab sahābīsecara sederhana dapat diartikan sebagai hasil ijtihād sahābat Nabi. Dalam kajian ushul fiqh, Mazhab sahābïini merupakan salah satu istilah teknis dan merupakan salah satu bagian dari dalil/sumber hukum yang mukhtalaf fih.

Abdul Karim Zaidan membagi pendapat sahābat ke dalam empat kategori yaitu, (1) fatwa sahābat yang bukan merupakan hasil ijtihād. Misalnya, Fatwa Ibnu Mas'ud, bahwa batas minimal waktu haidh tiga hari dan batas minimal mas kawin sebanyak sepuluh dirham. Fatwa-fatwa seperti ini bukan merupakan hasil ijtihād sahābat dan besar kemungkinan hal itu mereka terima dari Rasulullah. Oleh karena itu, fatwa-fatwa semacam ini disepakati menjadi landasan hukum bagi generasi sesudahnya, (2) fatwa sahābat yang disepakati secara tegas di kalangan mereka dikenal dengan ijma' sahābat. Fatwa seperti ini menjadi pegangan bagi generasi sesudahnya, (3) fatwa sahābat secara perorangan yang tidak mengikat sahābat yang lain. Para mujtahid di kalangan sahābat memang sering berbeda pendapat dalam satu masalah, namun dalam hal ini fatwa seorang sahābat tidak mengikat (diikuti) sahābat yang lain, dan (3) fatwa sahābat secara perorangan yang didasarkan oleh ra'yu dan ijtihād. ${ }^{33}$

\section{Kehujjahan Mazhab sahābì}

Maksud kehujjahan di sini adalah kekuatan yang mengikat untuk dijalankan oleh umat Islam, sehingga akan berdosa jika meninggalkannya sebagaimana berdosanya meninggalkan perintah Nabi. Pembicaraan tentang apakah Mazhab sahābì itu menyangkut beberapa segi pembahasan, yaitu: (1) pembahasan dari kehujjahannya terhadap sesama sahabat yang lain, dan kehujahannya terhadap generasi berikutnya atau orang yang selain sahabat, (2) pembahasan dari segi bentuk Mazhab sahābì, dapat dibedakan antara kemungkinannya berasal dari ijtihad pribadi sahabat tersebut atau melalui cara lain. Para ulama berbeda pendapat dalam hal ini, yaitu (1) pendapat sahabat yang berada di luar lingkup

${ }^{30}$ Istilah ini digunakan oleh Abu Zahrah dalam kitab Ushul al-Fiqh

${ }^{31}$ Istilah ini juga digunakan oleh Abu Zahrah dalam kitab Ushul al-Figh

${ }^{32}$ Istilah Mazhab al- Sahaby ini digunakan oleh Abdul Wahab Khallaf dalam kitabnya Ilmu Ushul al-Figh, Wahbah Al-Zuhaily dalam kitabnyaUshul al-Figh al-Islamy, Al-Amidy dalam kitabnya Al-Ihkam fi Ushul al-Ahkam.

${ }^{33}$ Abdul Karim Zaidan, Al-Wajiz fi Ushul al-Fiqh (Beirut: Muassasat Al-Risalah, 1985), h. 120. 
ijtihad (diluar masalah ta'abbudi atau hal lain yang secara qath'i berasal dari Nabi), meskipun secara terang tidak disebutkan berasal dari Nabi dapat menjadi hujjah. Bila terdapat dua pendapat atau lebih yang berbeda dalam bentuk ini, maka diselesaikan dengan cara atau metode yang lazim (berlaku), dan (2) pendapat sahabat dalam lingkup ijtihad dan bukan dalam bentuk tafiq, tentang kehujjahannya tergantung untuk siapa pendapat sahabat itu diberlakukan. Pada ulama sepakat bahwa pendapat sahabat dalam bentuk ini tidak menjadi hujjah untuk sesama sahabat lainnya, baik ia seorang imam, hakim atau mufti. Kesepakatan ulama ini dinukilkan oleh kebanyakan ahli ushul, di antaranya oleh al-Amidi. Demikian juga oleh dua pakar ushul fiqh, yaitu: Ibn Subki dan alAsnawi, yang mengajukan argumentasi, yakni (a) bila sahabat yang lain itu adalah mujtahid, maka pendapat seorang sahabat tidak dapat diberlakukan bagi sahabat lainnya itu, karena seorang mujtahid tidak boleh bertaqlid kepada yang sesama sahabat lainnya. Kalau sahabat lain itu bukan mujtahid, tentu ia menjadi muqallid (bertaklid), namun hal ini lemah sifatnya karena, dan (b) ada ijma' di kalangan sahabat yang membolehkan seorang sahabat berbeda pendapat dengan sahabat lainnya. Hal ini menunjukkan bahwa pendapat seorang sahabat tidak mempunyai kekuatan yang mengikat terhadap sahabat lainnya. Tidak ada celaan dari seorang sahabat terhadap sahabat lain bila ia tidak sependapat. Hal ini menunjukkan bahwa pendapat seorang sahabat tidak mempunyai kekuatan yang mengikat bagi sahabat lainnya. ${ }^{34}$

Para ulama berbeda pendapat mengenai kehujjahan pendapat sahabat bagi orang lain yang selain sahabat, seperti: tabiin (generasi sesudah sahabat), tabi'tabiin (generasi sesudah tabi'in) dan generasi berikutnya. Mislanya, (1) pendapat kalangan ulama yang terdiri dari ulama kalam Asy'ariyah dan Mutazilah, Imam Syafii dalam satu qaulnya, Ahmed dalam satu riwayatnya, dan al-Karakhi dari ulama Malikiyah. Mereka mengatakar bahwa pendapat sahabat yang berasal dari ijtihadnya tidaklah menjadi hujjah bagi generasi sesudahnya. Pendapat inilah yang dipilih oleh al-Amidi. Mereka mengemukakan argument, yakni (a) firman Allah dalam surat al-Nisa' (4): 59 yang artinya jika kamu berselisih pendapat kembalikanlah kepada A 11ab dan Rasul. Dalam ayat ini ada perintah Allah untuk mengembalikan urusan kepada Allah dan Rasul bila terdapat perselisihan pendapat. Seandainya boleh mengambil pendapat sahabat, tentu Allah akan menyuruh umat berbuat demikian, (b) Ijma' sahabat tentang kebolehan beda pendapat antara sesama sahabat. Seandainya pendapat seorang sahabat itu menjadi hujjah, tentunya seorang sahabat wajib mengikuti yang lain, dan ini

${ }_{34}$ Amir Syarifuddin, Ushul Fiqh, Jilid II, (Cet. II; Jakarta; Logos Wacana Ilmu, 2001), h. 380. 
adalah mustahil, (c) sahabat mengemukakan pendapatnya berdasarkan hasil ijtihadnya bukan berdasarkan taufiq, sehingga ada kemungkinan pendapatnya itu salah. Karenanya, pendapat sahabat itu tidak berdaya hujjah, terhadap yang lain, (d) para sahabat terkadang berbeda pendapat dalam beberapa masalah. Sebagian sahabat mengikuti pendapat yang berbeda dengar pendapat sahabat yang lain. Kalau setiap pendapat sahabat menjadi hujjah terhadap sahabat lain dan orangorang sesudahnya, tentu hujjah-hujjah Allah itu berbeda atau berbenturan satu sarna lain. Mengikuti pendapat sebagian sahabat tidaklah lebih baik dibandingkan dengar pendapat sahabat yang lain, dan (2) pendapat kalangan ulama yang terdiri dari: Malik ibn Anas, al-Razi al-Barzai dari sahabat Abu Hanifah, al-Syafii dalam salah satu qaulnya (qaul qadim), dan Ahmad dalam salah satu riwayatnya. Mereka berpendapat bahwa pendapat sahabat itu menjadi hujjah secara mutlak. Mereka mengemukakan argumen bahwa (a) firman Allah dalam surat Ali Ymrain (3): 110 yang artinya Kamu adalab umat terbaik yang dikeluarkan kepada manusia, menyeruh berbuat ma'ruf. Ayat ini merupakan khitab yang diarahkan pads umat yang menjelas kan bahwa, apa yang disuruh sahabat itu adalah ma'ruf sedangkan berbuat yang maruf itu wajib hukumnya, dan (b) sabda Nabi: Para sdubatku adalah laksana bintang gemintang; siapa pun yang kamu ikuti kamu akan mendapat petunjuk.Hadits ini mengisyaratkan untuk mengikuti apa yang diberikan oleh sahabat Nabi. Hal ini menunjukkan kehujjahan pendapat yang disampaikan oleh sahabat. ${ }^{35}$

Dalam beberapa literatur ushul fiqh, dikemukakan pendapat para ulama yang berpandangan bahwa kehujjahan pendapat sahabat itu adalah secara terbatas bagi sahabat-sahabat tertentu saja. Beberapa pendapat mereka adalah (1) pendapat sahabat yang berdaya hujjah hanyalah bila lahir dari Abu Bakar dan Umar ibn Khattab bersama-sama. Dasarnya adalah hadits Nabi yang menyatakan Ikutlah dua orang sesudahku yaitu AbuBakar dan Umar, (2) pendapat empat orang dari khulafa al-Rasyidin menjadi hujjah dan tidak dari sahabat lainnya. Dasarnya dalah hadits Nabi yang dishahihkan oleh Turmudzi: "Adalah kewajibanmu untuk mengikuti sunnabku dan sunnab Kbulafa al-Rasyidin yang datang sesudahku”, (3) pendapat salah seorang Khulafa al-Rasyidin selain Ali menjadi hujjah. Pendapat ini dinukilkan dari al-Syafii. Tidak dirnasukkannya Ali dalam kelompok sahabat ini oleh al-Syafii bukan karena kurang dari segi kualitasnya dibandingkan pendahulunya, tetapi karena setelah menjadi khalifah ia memindahkan kedudukannya ke Kufah dan waktu itu pars sahabat yang biasa menjadi nara somber bagi khalifah dalam forum musyawarah pads mass sebelum 'Ali sudah tidak ada lagi, (3) pendapat dari sahabat yang mendapat keistimewaan

35 Ibid., h. 382. 
pribadi dari Nabi menjadi hujjah bila ia berbicara dalam bidang keistimewaannya itu, seperti Zaid ibn Tsabit dalam bidang faraid (hukum waris); Muaz ibn Jabal dalam bidang hukum di luar faraid, dan Ali ibn Abi Thalib, dalam masalah peradilan. $^{36}$

Berdasarkan beberapa analisis tentang Mazhab sahābì secara teoritis di atas, maka penulis menemukan bahwa sebaran Sahābat yang memiliki kualifikasi sebagai mujtahid pada masa sahabat memiliki beberapa implikasi terhadap Mazhab sahābì yaitu sebagai (1) terjadinya pengkategorian/pengelompokkan pendapat Sahābat dalam Mazhab sahābì dipengaruhi oleh sebaran Sahābat, dan (2) terjadinya berbagai pandangan/pendapat ulama terhadap kehujjahan Mazhab sahābì tidak terlepas dari peta sebaran Sahābat pada masa Al-Khulafã' AlRāsyidūn terutama pada masa tabi'in dan imam mazhab.

\section{Penutup}

Kasimulan yang dapat diambil dari penjelasan sebelumnya adalah bahwa sahābat yang dapat disebut memiliki kualifikasi sebagai mujtahid adalah Sahābat yang memiliki fatwa pribadi dalam bidang hukum Islam. Kemudian daerah-daerah yang menjadi sebaran mujtahid yang memiliki kualifikasi mujtahid pada masa alkhulafa'-al-rasyidun adalah: Madinah, Makkah, Kufah, Bashrah, Syam dan Mesir.

Sebaran Sahābat yang memiliki kualifikasi sebagai mujtahid pada masa sahabat memiliki beberapa implikasi terhadap mazhab sahabiy yaitu sebagai berikut. Adapun munculnya pengkategorian/pengelompokkan pendapat Sahābat dalam mazhab sahabiy dipengaruhi oleh sebaran Sahābat.

Terjadinya berbagai pandangan/pendapat ulama terhadap kehujjahan mazhab sahabiy tidak terlepas dari peta sebaran Sahābat pada masa sahabat terutama pada masa tabi'in dan imam mazhab.

\footnotetext{
36 Ibid., h. 384.
} 


\section{Daftar Rujukan}

Ahmad Rofiq. Pembaharuan Hukum Islam di Indonesia. Cet. I; Yogyakarta: Gama Media, 2001.

Ahmad Warson Munawwir. Al-Munawwir: Kamus Arab Indonesia, Yogyakarta: Krapyak, 1984.

Al-Asqalani, Ahmad bin 'Ali bin Hajar. Al-Ishabah Fii Tamyizi Al-Sahabah. Juz. I, (Mesir: Al-Maktabah Al-Taufiqiyah, t.th.

al-Asyqar, Umar Sulaiman. Fiqh Islam: Sejarah Pembentukan dan Perkembangannya. Cet. I; Jakarta: Akademika Pressindo, 2001.

Al-Baltaji, Muhyiddin Abdussalam. Mauqif Al-Imam Al-Syafi'i Min Madrasah Al-Iraq Al-Fiqhiyyah. Mesir, t.th.

al-Bāqy,Muhammad Fuād 'Abd. Al-Mu'jam al-Mufahras li al-Fāž alQur’an al-Karīm. Cet. I; Mesir: Dār al Hadith, 1996.

Al-Halawi, Muhammad Abdul Aziz. Fatwa dan Ijtihad Umar bin Khaththab: Ensiklopedia Berbagai Persoalan Fiqh. Cet. I; Surabaya: Risalah Gusti, 1999.

al-Khallaf, Abdul Wahhab. 'Ilm Ushul al-Fiqh. Cet. XII; Mesir: Dar al-Ilm, 1978.

Al-Khatib, Hasan Ahmad. Al-Fiqh al-Muqaran. Mesir: Dar al Talif, 1957.

al-Khatib, Muhammad Ajjaj. Ushul al-Hadis Ulumuhu wa Mustalahuhu. Beirut: Dar al-Fikr, 1989.

al-Qaththan, Manna'. Tarikh al-Tasryi' al Islami. Cet. VII; Beirut: Muassasat alRisalah, 1987.

al-Qusyairy, Abul Husain Muslim bin Al-Hajjaj. Sahih Muslim. Jilid II, Beirut: Dar al-Kut-b al-Ilmiyah, t.th.

Al-Sāyis, Muhammad Ali. Tārikh al-Fiqh al-Islām. Cet; Beirut: Dār al-Kutub alIlmiyyah, 1990.

al-Shadr, Baqir. A Short History of Ilmu Ush-1 dan Murtadha Mutahhari, Jurisprudende and Its Priceples. Diterjemahkan oleh Satrio Pinadito dan Ahsin Muhammad dengan judul Pengantar Ushul Fiqh dan Ilmu Ushul Perbandingan. Cet. I; Jakarta: Pustaka Hidayah, 1993.

Alyasa' Abu Bakar. Fatwa Sahabat Sebagai Paradigma Fiqih Mazhab. [Makalah], Banda Aceh, 25 Agustus 2004. 
al-Zāwy, Al-Tāhir Ahmad. Tartib al-Qamus al-Muhìt. Juz. III; Cet. III; Beirut: Dār al-Fikr, t,th

Al-Zuhaili, Wahbah. Ushul Fiqh Al-Islami. Juz II, Cet. III; Surya: Dar Al-Fikr, 2005.

Amin, Ahmad. Fajr al-Islam. Cet. XI; Mesir: Dar al-Fikr, 1975.

Amir Syarifuddin. Ushul Fiqh. Jilid II, Cet. II; Jakarta; Logos Wacana Ilmu, 2001.

Ananda, Faisar. Sejarah Pembentukan Hukum Islam; Studi Tentang Hukum Islam di Barat. Cet I; Jakarta: Pustaka Firdaus, 1996.

Badr, Abdullah Abu Assu'ud. Tafsir Ummul Mukminin Aisyah Radiallahu 'Anha. Diterjemahkan dalam bahasa Indonesia dengan judul Tafsir Aisyah. Cet. I; Jakarta: PT Serambi Ilmu Semesta, 2000.

Baltaji, Muhammad. Metodologi Ijtihad Umar bin Khathab, Cet. I; Jakarta: Khalifah, 2005.

Bek, Ahmad Ibrahim. Ilmu Ushul al-Fiqh wa Yalih Tarikh al-Tasyri' alIslam. Mesir: Dar al-Anshar, 1939.

Bek, Syaikh Muhammad al-Khudari. Tarikh al-Tasyri' Al-Islami. Beirut: Dār al-Fikr, t.th..

El-Fadl, Khaled M Abou. Atas Nama Tuhan: Dari Fikih Otoriter ke Fikih Otoritatif. Cet. I; Jakarta: PT Serambi Ilmu Nusantara, 2004.

Fuad Jabali. A Sudy of The Companions Of The Prophet: Geographical Distribution And Political Alignments. [Disertasi], Montreal: McGill University, 1999.

Hasan, Ahmad, The Early Development of Islamic Jurisprudence, Cet.I; India: Adam Fublisher and Distributors, 1994.

Hazm, Abi Muhammad Ali bin Ahmad bin Said bin. Al-Ihkam Fi Ushul alAhkam. Jilid V, Beirut: Dar Al-Kutub Al-Ilmiyyah, t.th.

Ismail, Sya'ba Muhammad. al-Tasyri' al-Islāmi: Mashādiruhu wa 'Athwāruhu. Cet. III; Mesir: Maktabat al-Nahdhat al-Mishriyyah, 1975.

Khallaf, Abdul Wahab. Ilmu Ushūl al-fiqh wa Khulāshat al-Tasyri alIslām. Mesir: t.p. 1942. 
Lapidus, Ira M. A History of Islam Societies. Diterjemahkan oleh Ghufran A Mas'adi dengan judul. Sejarah Sosial Umat Islam. Cet. I; Jakarta: PT RajaGrafindo Persada, 1999.

M. Hasbi Ash-Shiddieqiy. Sejarah dan Pengantar Ilmu Al-Qur'an/Tafsir. Cet. XIV; Jakarta: PT. Bulan Bintang, 1992.

Minhaji, Ahmad, Kontroversi Pembentukan Hukum Islam. Cet. I; Yogyakarta: UII Press, 2001.

Mun'im A. Sirry, Sejarah Fiqh Islam: Sebuah Pengantar. Cet. II; Surabaya: Risalah Gusti, 1996.

Musa, Muhammad Yusuf. Al-Madkhal Li Dirāsat al-Fiqh al-Islām. Mesir: Dār al-Fikr al-Araby, 1961.

Qardhawi, Yusuf. Madkhal li Dirasat al-Syari'at al-Islamiyah. Cet. I; Beirut: Muassasat al-Risalah, 1993.

Saifuddin, Achmad Fedyani. Antropologi Kontemporer: Suatu Pengantar Kritis Mengenai Paradigma. Cet. I; Jakarta: Kencana, 2005.

Saurah, Abu Isa Dirham bin Isa ibn. Sunan Al- Turmudzi. Juz IV; Beirut: Dar alKut-b al-Ilmiyah, 1987.

Sulaiman, Abdul Wahab Ibrahim Abu. Kitab Tartib al-Maudhu'at al- Fiqhiyyah wa Munasabatuhn fi al-Mazahib al-Arba'ah. Diterjemahkan oleh Agil Husain al-Munawwar, Cet. I; Semarang: CV. Toha Putra, 1993.

Syaltut, Mahmud. Al-Islam 'Aqidah wa Syari'ah. Kairo: Dār al-Qalam, 1966.

Tim Penyusun Kamus Pusat Bahasa. Kamus Besar Bahasa Indonesia, Edisi III, Cet. III; Jakarta: Balai Pustaka, 2005.

Zahrah, Muhammad Abu. Ushul al-Fiqh. Mesir: Dār al-Fikr al-Araby, 1958.

Zaidan, Abdul Karim. Al-Wajiz fi Ushul al-Fiqh. Beirut: Muassasat Al-Risalah, 1985.

Zakariyyah, Abi al Husain Ahmad Ibnu Fāris. Mu’jam Maqāyis al-Lugah. Juz III; Beirut: Dār al-Fikr, t.th. 